\section{Genetic weaponry?}

SIR - The problems of implementing the Helsinki accords in Soviet Russia have been raised once more in your issue of 15 February (p.437) where the case of David Goldfarb was mentioned. I have known David Goldfarb for many years. He was head of the Laboratory of Molecular Genetics of Bacteria and

Bacteriophage of the Soviet Academy of Sciences. He has asked to emigrate to Israel and a visa was denied on the grounds that "he had access to classified work".

David Goldfarb was never involved in classified work and did not even have security clearance - as so many scientists in Soviet Russia have. He worked on the genetics of bacteria and bacteriophage. If such research is classified, it means that Soviet Russia intends to use molecular genetics for biological warfare.

So far as is known, the USSR Academy of Sciences is consulted when a scientist asks for an emigration visa. One wonders if the Academy will officially and openly subscribe to the decision of the Soviet authorities according to which molecular genetics is a potential weapon and a military secret.

ANDRE LWOFF

Institut Pasteur, Paris, France

\section{NRPB and risk}

SIR - It must be admitted that one does not know what happens within an organization without being a part of it. It is equally true that being a part does not automatically make one a reliable critic of it. We have these assertions in mind upon reading $\mathrm{Mr} \mathrm{S}$. G. Goss's letter on risks at the National Radiological Protection Board (Nature 289, 316 ; 1980).

We have the highest respect for the scientific integrity of Sir Edward Pochin and the late Dr G. W. Dolphin, and their thoughtful attempts to publish reliable information on radiation risks.

We further believe that this view is shared by other US colleagues who have had the opportunity of interacting with these two. Derogatory evidence would have to have a decidedly firmer foundation than that offered in the Goss letter to change this viewpoint. WILLIAM J. BAIR ROY C. THOMPSON Herbert M. PARKer Battelle Pacific Northwest Laboratories, Richland, Washington, USA

\section{Conservation sites}

SIR - In his letter of 12 March 1981, Dr C. Muir criticises actions and advice of the Nature Conservancy Council (NCC) over Sites of Special Scientific Interest (SSSI) on the grounds that such sites are misguidedly chosen to protect endangered species, because species extinction is a natural and inevitable process; and that the site notification procedure imposes an unacceptable financial burden on landowners. The NCC does not notify SSSIs from "caprice"' but because Parliament in its wisdom conferred this duty upon us, as a key part of a national strategy for nature conservation. We continue to do this because a very large number of concerned people believe that SSSIs are important to the conservation of wildlife and physical features.

Most extinctions during the last 2,000 years have been man-induced, and it is this accelerated loss that we are trying to stem. By
$2000 \mathrm{AD}$ the world will have lost no fewer than one million of the plant and animal species existing today, mainly through habitat destruction and over-exploitation. In Britain many indigenous species could become extinct. Whether this is held to be evolution or not is irrelevant: the fact is that many people do not wish such losses to occur and look to NCC and other bodies to prevent them.

SSSIs are in any case not chosen just for the presence of rare or endangered species, but to give a national network of important seminatural habitats. Many are selected quite separately for the importance of their geological and physiographic features. The term "scientific interest" is interpreted broadly as the value of the biological and physical attributes of a site to that informed sector of society which has a concern for such phenomena. The NCC has defined criteria for evaluation of these attributes based on the full range of public interest involved, which is clearly wider than scientists alone.

The SSSI device is one of the few means available for defending the important areas for nature conservation but its actual inadequacy in this respect is currently the subject of lengthy parliamentary debate on the Wildlife and Countryside Bill. Our concern is indeed to safeguard these sites in perpetuity. It is a staggeringly narrow and mechanistic view which holds that once "objects or phenomena" have been "studied" they are of no further value to science and can, by implication, be allowed to disappear. And beyond this, who has the confidence to assert that all possible knowledge has been gleaned from any object or phenomenon?

The responsibility of government to cater for nature conservation as a public interest is not, in a democratic society, altered by the fact that some people find the resulting measures inconvenient to their material interests or irrelevant to their personal beliefs. And just to get things in proportion, the sense of official priority accorded to nature conservation in public affairs is reflected in the $£ 10$ million annual budget of NCC, compared with $£ 700$ million allocated to agricultural support and $£ 9,500$ million to defence.

The NCC has long accepted that when owners and occupiers of land are asked to incur a material loss in order to sustain a nature conservation interest, the principle of compensatory payment is entirely fair. This principle would remain an integral part of the additional site safeguard measures which NCC has been seeking in the Wildlife and Countryside Bill. It seems equally reasonable to ask that owners and occupiers of land accept that they have, on behalf of the nation, a responsibility in stewardship for the national heritage of nature which is now suffering such severe and accelerating losses. We are all increasingly enmeshed in a single society, and when the owners and managers of our national resources ask the taxpayer to help their private circumstances by direct or indirect cash handouts, another point of principle arises. This is that these parties should also accept that such funds are distributed across the whole wide spectrum of taxpayer interests, according to a balance of adjudication through the proper agencies of government, of which NCC is one.

Nature Conservancy Council

D. A. RadcliffE

London SWI, UK

\section{Selling Darwin}

SIR - So much has been written on Darwin and Marx, since Halstead's original diatribe against the use of cladistics in the displays of the Natural History Museum (Nature 288; 208; 1980 ), that I wonder whether these two venerable gentlemen are not now reaching for their pens to set the record straight. Until Nature's Olympian warnings (26 February, p.735) on the "selling out on Darwinism" in the museum (and by association other new evolutionary approaches) one felt safe from the bogies in Halstead's head. Now that they are out and about rather than dead and buried, it is amusing to consider the original error which gave rise to them.

Halstead's polemics "follow like a tedious argument of insidious intent" (T. S. Eliot). His accusation that cladists and proponents of "punctuated equilibria" are furthering the Marxist concept of dialectical materialism reveals his ignorance of the fundamentals of this concept and of Darwinism. If it is necessary to find a biological phenomenon in keeping with dialectical materialism, then Darwin and not "punctuated equilibria" provides a perfect example. According to dialectical materialism (unsullied version) there are two inter-related components to every process in that a gradual accumulation of small quantitative changes leads inevitably to a qualitative change of state. Engel's favourite scientific example was the boiling of water. A qualitative change from liquid to gas only occurs after a sufficient quantitative increase in the thermal agitation of the molecules has taken place. According to popular Darwinism a gradual quantitative accumulation of allelic differences as an adaptive response to a specific environment leads inevitably to a qualitative change of state (the inception of reproductive isolation: speciation). If dialectical materialism upsets Halstead he would do better to dismantle 130 years of Darwinism.

Ironically the precise mechanism by which natural selection could increase reproductive isolation perplexed Darwin and, despite the subsequent attempts of Fisher, Muller and Dobzhansky to explain how this might happen, we have little empirical data. "Let me first say that no man could have more earnestly wished for the success of Natural Selection in regard to sterility than I did, I always felt sure it would be worked out but always failed in detail." (Darwin: letters to Wallace and Huxley). Notwithstanding these doubts and lack of data Darwinism flourishes today as an explanatory mechanism of adaptation that leads to speciation.

The theory of "punctuated equilibria" does not see species formation necessarily as the inevitable consequence of microevolutionary adaptive differences. It dissociates (to an extent) quantitative (microevolutionary) from qualitative (macroevolutionary) phenomena. Thus with regard to the process of adaptation, it is Darwinian. With regard to the process of speciation, there are several current notions (ranging from possible developmental constraints on phylogenetic progress to possible biological effects of saltatory and rapidly spreading changes in genome organization) that, although novel to a degree, leave no room for instant creationism or the demise of Darwin, in the way it is construed. 